\title{
A critical test of the concept of submarine equilibrium profile
}

Aggeliki Georgiopoulou ${ }^{\mathrm{a}, \mathrm{b}, *}$ and Joseph A Cartwright ${ }^{\mathrm{a}}$

a 3DLab, School of Earth and Ocean Sciences, Cardiff University, Main Building, Park Place, CF10 3YE, Wales, UK,

${ }^{\mathrm{b}}$ UCD School of Geological Sciences, University College Dublin, Science Centre (West), Belfield, Dublin 4, Republic of Ireland

* Corresponding author: aggie.georg@ucd.ie; tel: +353 1716 2063; fax: +353 1283 7733

Keywords: submarine equilibrium profile; submarine channel; normal fault; fault linkage; Nile Delta

\begin{abstract}
The existence of a slope equilibrium profile has been widely used to account for erosional and depositional processes on submarine slopes and turbidite systems. Profiles out-ofequilibrium are commonly observed in actively deforming areas where channels seem to be deflected or diverted by seafloor structures. In this study the concept of the submarine equilibrium profile is tested in an area of extensive surface faulting to examine whether channels adopt an equilibrium-type profile through time. The study area is on the slope of the Nile Delta, which is disrupted by a number of surface-rupturing normal faults. Prior
\end{abstract}


to fault linkage, several submarine channels flowed down the slope and either utilised relay ramps or flowed through fault scarps of the fault array. Where a relay ramp had been utilised, post fault linkage, the channels of the area either avulsed or converged into one major channel in response to a change in the deformed slope profile to a more concave shape. The thalweg of the post fault linkage channel and two slope profiles either side of it are measured in the area of the fault array, to understand how the channel evolved in response to the active faulting. When fault displacement is relatively small the combination of channel erosion and aggradation results in a channel thalweg profile nearequilibrium with predictable modifications of channel dimensions (depth and width) even if sediment supply was infrequent and episodic. It is concluded that turbidite channels can conform to the concept of equilibrium and submarine base level if it is the most energy efficient route for submarine gravity flows downslope. The most energy efficient route will be one where flows bypass the slope without eroding or depositing and move in a direct downslope course towards base level.

\section{Introduction}

When it comes to defining base level and slope equilibrium there appears to be lack of consensus in the scientific community and as a result interpreters have often assigned their own definitions pointing to the interpretative nature of the concept. The terms "base level” and "equilibrium profile” have been lent to submarine sedimentary processes from the terrestrial fluvial realm and the interchangeable use of the same terms for continentaland marine-based studies can be confusing. Base level in the submarine environment is generally defined as the deepest point in the basin that can be reached by gravity flows 
(Carter, 1988; Pirmez and Flood, 1995) while some researchers insist on referring to sea level as base level ( e.g. Catuneanu, 2002) (Fig. 1).

Pirmez et al. (2000) defined the equilibrium profile as a depth profile created by the erosional and aggradational action of turbidity currents over a period of thousands of years such that the prevailing sediment discharge is carried through the channel with minimum aggradation or degradation (Fig. 1). When trying to determine what type of slope is in a state of 'slope equilibrium', researchers are faced with the added challenge that the ocean system is not a steady-state system and therefore the equilibrium profile itself will also be transient. An equilibrium profile will therefore depend on indirect factors such as ocean current regime, slope stability and strength of near-seafloor sediments amongst other factors that more directly impact the ability of a channel to erode or aggrade to a specific datum, such as power and frequency of flows, geometry of flows and availability of sediment being transported by those flows (Kneller, 2003).

In this paper we consider the equilibrium profile as a notional surface which the channel thalweg evolves towards under a given set of boundary conditions, namely the starting configuration of the thalweg. Where sedimentary transport processes are the dominant shaping mechanism, the equilibrium profile tends to assume a concave-up thalweg profile (Ferry et al., 2005). However, for slopes that are being actively deformed by faulting or folding it is not clear whether the same notional surface governs the evolutionary behaviour. Where the rates of tectonic deformation are comparable to the sediment flux, the thalweg profile is likely to smooth irregularities but reflect in part the motion of active structures (Pirmez et al., 2000). But what behaviour could be expected if flow frequency down the channel is low? It could be postulated that whatever the 
magnitude of the deformation of the slope, the natural tendency of a channel will be to adjust its slope profile until it reaches the equilibrium profile (Ferry et al. 2005). Even during continuous structural growth the profile could well be maintained in a state of disequilibrium but the gravity flows will attempt to bring it to a state of equilibrium through slope adjustments, but this possibility has not been documented in detail, so the specific behaviour is unknown. This study examines this situation, where structural growth is ongoing (normal faults) but sediment supply is intermittent.

\section{Submarine channels and seafloor tectonic deformation}

Where channels interact with seafloor structures, such as fault escarpments and folds, they are most commonly deflected by them (Catterall et al., 2010; Clark and Cartwright, 2009; Cronin et al., 2005; Cross et al., 2009; Mayall et al., 2010). This observation suggests that pre-existing seafloor topography and/or tectonic movement create slope profiles that are out of equilibrium and that the rate of incision is slower than the rate of

uplift. For example, on the eastern part of the Nile Delta slope, channels have been shown to respond to topography in four dominant ways; confinement, diversion, deflection and blocking, with no examples of channels cross cutting structures (Clark and Cartwright, 2009).

However, it has often been argued that the longitudinal slope profiles of submarine channels tend towards equilibrium and will erode and/or deposit in their effort to adjust to the equilibrium profile (Ferry et al., 2005; Heiniö and Davies, 2007; Pirmez et al., 2000; Prather et al., 1998). A classic example of this process of adjustment to a notional equilibrium can be seen in the salt-controlled minibasins of the Gulf of Mexico. Here, it 
has been shown that the seismic facies distribution and stratigraphic relationships follow a fill-and-spill model that is determined by the slope profile and the degree to which any depositional surface approximates to that surface of equilibrium (Prather et al., 1998). Specific examples of conformance to the equilibrium have been explained by local factors where knickpoints are formed. A knickpoint is a disruption in the equilibrium profile and in fluvial systems it is defined as a section of steep gradient between lower gradient sections along a river course (Howard et al., 1994). Heiniö and Davies (2007) identified knickpoints on deeply incised channels on the mid-slope region of the Niger Delta and argued that these result from the deep incision and therefore high degree of confinement of channels, meaning that they cannot migrate laterally in response to the changing morphology and instead the profile adjusts vertically to the equilibrium profile.

Mayall et al. (2010) recently identified the lack of published work on the interaction between evolving seafloor structures and synkinematic sedimentary systems. Therefore, it is not clear whether the concept of equilibrium profile is useful when trying to explain channel-structure interactions.

Submarine channels are generally regarded as physiographic connections between canyons that incise the continental slope (whether they are a seaward continuation of a continental river system or not) and the deep ocean floor, where slope gradient becomes less than 1:1000 (Carter, 1988). There have been studies, albeit few in number, regarding the concept of equilibrium profile in submarine channels, which have considered large fans such as the Amazon Fan, the Rhône Fan, the Niger Delta Fan, the Congo Fan (Ferry et al., 2005; Pirmez et al., 2000) as well as the Nile Deep Sea Fan (Catterall et al., 2010). These settings are dominated by the supply of large amounts of sediment from large 
subaerial deltas that extend into the deep-water environment. Their submarine equivalents start at the shelf edge and extend for 100's of kilometres downslope. So apart from whether channels adhere to the "law" of adjustment to the equilibrium profile in general the question arises whether that process is also applicable to smaller scale channels with limited and episodic sediment input, not connected to a sediment source on the continental shelf.

The aim of this study is to test the concept of the equilibrium profile on a relatively small submarine channel in the area of the Western Nile Delta that is tectonically modified by a series of syndepositional normal faults distributed along the length of the channel. The channel is part of a network of similar sized channels in this area of the slope, and it does not receive a constant supply of sediments due to its lack of direct connection to the major feeder points near the shelf break. The head of the channel is located approximately $60 \mathrm{~km}$ seaward of the shelf break, at $600 \mathrm{~m}$ water depth and does not appear to be linked with a delta distributary channel upslope (the Nile Delta), nor does it seem to be directly related to a point source of sediments on the continental shelf (the Rosetta submarine channel). Therefore flows through it are unlikely to be hyperpycnal flows and are more likely to be dominated by surge-type turbulent flows (Mulder et al., 2003).

The thalweg profile adjustment is documented in order to evaluate how the channel has adjusted to the local deformation resulting from the active faulting. The relative timing of these adjustments and the structural movements are also considered. It is shown that in spite of the relatively small dimensions of this channel, it is able to adjust to local hangingwall subsidence through aggradation, and to local footwall uplift through 
incision, such that an almost perfectly smooth profile results. Finally, the wider significance of this simple example is considered in terms of slope processes in general, and specifically for the notion of the equilibrium profile in tectonically active areas.

\section{Regional setting}

The Eastern Mediterranean basin is dominated by the Nile deep-sea turbidite system. The area is governed by a complex interaction of active and varied crustal tectonics (Kreemer and Chamot-Rooke, 2004; Le Pichon et al., 1995; Mascle et al., 2001; McClusky et al., 2000; Westaway, 1994). To the north, the African plate is colliding with and subducting underneath the Eurasian plate and the rapidly westward moving AegeanAnatolian microplate, creating the Hellenic and Cyprus arcs (Aal et al., 2000) (Fig. 2). To the east, the Levant margin is controlled by the eastward relative movement of the Arabian plate along the East Anatolian fault zone and northeastward along the Dead Sea shear zone (Mascle et al., 2000) (Fig. 2). To the south, the North African passive margin is draped by the thick sedimentary wedge of the Nile deep-sea fan (NDSF), constructed mostly since the late Miocene (Loncke et al., 2006) with a postulated thickness exceeding $9 \mathrm{~km}$ (Aal et al., 2000). Added to this complexity are the consequences of gravity-driven salt tectonics caused by loading of ductile salt layers deposited during the Messinian Salinity Crisis (latest Miocene) with the thick Plio-Quaternary sediments of the NDSF (Loncke et al., 2006; Ross and Uchupi, 1977).

Three morphotectonic provinces are distinguished in the NDSF from west to east; the Western, Central, (Fig. 2A) and Eastern Provinces (Bellaiche et al., 2001; Bellaiche et al., 1999; Loncke et al., 2002; Loncke et al., 2009; Mascle et al., 2006; Mascle et al., 2001). 
Here we focus on the Western Province which is dominated by submarine channels and active normal faults as well as mass transport complexes (Garziglia et al., 2008; Loncke et al., 2009) (Fig. 2).

\section{The Western Nile Deep-Sea Fan Province}

The modern physiography of the delta is expressed in a continental shelf with variable width, between $64 \mathrm{~km}$ at the widest, but as narrow as $10 \mathrm{~km}$ off rocky headlands (Ross and Uchupi, 1977). The shelf edge is at 75-90 m water depth west of Alexandria but deepens to 150-265 m between the Rosetta and Damietta branches most likely because of the weight of the delta downwarping the shelf in this location (Ross and Uchupi, 1977).

Sediment transport across the western province is currently taking place through sinuous channels and distributaries, as well as slope failures with vertical scars up to 100 m high (Garziglia et al., 2008; Mascle et al., 2001). The channels are characterised by avulsion and appear to have progressively migrated westwards (Mascle et al., 2006). Upper slope failures have been invoked to explain the frequent modifications of channel positions, shapes and architecture in the area (Ducassou et al., 2009; Mascle et al., 2006). The slope instabilities are believed to have been triggered by enhanced sediment overloading in conjunction with underlying ductile deformation of the evaporites (Mascle et al., 2001). Arcuate growth faults cutting through the Pliocene-Quaternary sediments, rooted in the underlying ductile Messinian salt layers and associated with elongate salt walls, reportedly move northwards and generate typical raft-tectonic features (Mascle et al., 2001) (Fig. 2A). Also present on the seafloor in the Western 
Province are mud expulsion (mud volcanoes) (Fig. 2B) and fluid escape features (pockmarks) (Loncke and Mascle, 2004).

\section{Dataset and methodology}

The study has been performed on a 3D seismic dataset collected by the oil and gas industry. The seismic data is near zero-phase with SEG normal polarity, i.e. an increase in acoustic impedance is represented by a positive amplitude excursion on the seismic trace. The initial acquisition inline trace interval was $25 \mathrm{~m}$ with line spacing of $25 \mathrm{~m}$ and a sampling interval of $4 \mathrm{~ms}$. The dominant frequency of the dataset varies with depth, but it is approximately $45 \mathrm{~Hz}$ for the top one second of sediments, with estimated vertical stratigraphic resolution of c. $9 \mathrm{~m}$ considering an average velocity of $1600 \mathrm{~m} \mathrm{~s}^{-1}$ as calculated from the checkshot survey of a nearby well. The available dataset has been clipped below the Provider interpreted Top Messinian reflector.

In order to evaluate the channel response to seabed faulting the following morphometric parameters were measured (Fig. 3):

- Channel thalweg depth: depth from adjacent seafloor (channel rim) to present-day floor of the channel.

- Channel width: measured horizontally between levee/margin crests, perpendicular to the channel axis.

Measurements were taken at $250 \mathrm{~m}$ intervals along the length of the channel, although in some segments of the channel the interval was narrowed to $100 \mathrm{~m}$ as more closely spaced measurements were deemed necessary due to the small spacing between faults that cut the channel profile. In addition, slope profiles of the channel thalweg and the seafloor 
either side of the channel were generated in order to compare and contrast the slope morphologies and assess whether the channel profile adheres to the concept of a slope at equilibrium. Slope profiles were measured perpendicular to the bathymetric contours. Slope profiles are often used to understand the response of flow processes to deformation processes (e.g. (Arzola et al., 2008; Catterall et al., 2010; Ferry et al., 2005; Gardner, 1983; Gerber et al., 2009; Lastras et al., 2009).

Fault 50 (Figs 2B and 2C), the largest fault that crosses the channel was analysed in detail by mapping the seismic reflection which signifies the onset of faulting as well as key horizons at different stratigraphic levels using Schlumberger Geoframe 4.2 seismic interpretation software. Mapping of marker horizons was difficult due to; 1) problems with correlation across faults, 2) the presence of buried channels and slide deposits that disrupt the continuity of the reflections; and 3) data quality. Three marker horizons were, however, mapped using arbitrary lines from the 3D grid that directly tied footwall and hangingwall stratigraphy, and thus allowed displacement mapping to be undertaken for Fault F50 which is the major fault that crosses the channel (Fig. 4). Measurements of the throw values on the fault were made using fault-normal seismic profiles and displayed as a throw distribution plot along the length of the fault for four reflector horizons following standard procedures used in fault analysis (Barnett et al., 1987) (Fig. 4). A sound velovity of $1500 \mathrm{~m} \mathrm{~s}^{-1}$ was used to convert the throw values at the seafloor into metres.

RMS amplitude maps and isochron thickness distribution maps were generated to establish the evolution of the channel through time and its relationship with the faults that traverse it and in particular fault F50. 
The stratigraphic interval of interest for this study is the Late Pleistocene to recent, although precise dating of horizons has not been possible because the nearest wells are some $30 \mathrm{~km}$ away and there is no information in those wells on the youngest part of the stratigraphic succession.

\section{Results}

A description of the analysis and observations on the fault array, particularly the main fault (F50), is presented in this section. Subsequently the channel, its infill, its profile and history as well as profiles of the adjacent seafloor are described.

\subsection{General description of the fault array}

Seven major normal faults (shown with F) and more than twenty smaller ones are observed in this study (shown with small f). The mapped fault traces are linear to curvilinear, orientated E-W to ENE-WSW (Fig. 2). They strike perpendicular to the general slope direction, and dip on average $75^{\circ}$ northwards (downslope), except for some antithetic faults (F60, F70, f43, f45a, f45b, f48a, f49a) with similar dip angles but to the south (upslope) (Fig. 2). Some faults are curved in the central region creating an irregular and highly segmented shape, which typically results from the growth of the fault by segment linkage (e.g. F10, F40) (Fig. 2) (Cartwright et al., 1995). Curving at the edges of faults occurs when faults are closely spaced and the tips of one fault mechanically interact with a neighbouring fault (Baudon and Cartwright, 2008).

At the seabed the major faults show maximum scarp heights of $130 \mathrm{~m}$ (F40) while the smaller ones show scarps of around $50 \mathrm{~m}$. Fault scarps at the seabed suggest that the 
rate of fault movement is higher than sediment deposition. Dip angles are up to $71^{\circ}$ although these are reduced to some extent due to erosional scarp degradation.

\subsubsection{Onset of faulting}

The timing of the onset of faulting was determined by correlation and mapping of a series of horizons across the faults, and by evaluating the growth indices using standard techniques developed for the analysis of growth fault kinematics (Cartwright et al. 1998, and references therein). The onset of faulting is defined by the youngest reflection separating a seismic package of constant thickness across the fault below and a seismic package of increasing thickness across the fault above, i.e. the growth package (P50 in Fig. 4c). Fault onset appears to be contemporaneous across the study area since the marker horizon defining fault growth onset is correlatable as a single reflection throughout the area for all the measured faults.

\subsubsection{Fault 50}

Fault 50 shows the greatest displacement $(225 \mathrm{~m})$ of all the faults in the study area and has a strike length of $\sim 17 \mathrm{~km}$. The greatest displacement along this fault is located at the fault segment centre, which is typical of displacement distributions on normal faults (Fig. 4a) (Walsh and Watterson, 1987). Smaller faults are located at its western tip and the fault trace itself contains two sharp changes in orientation (points $\mathrm{X}$ and $\mathrm{Y}$ in Fig. 2B) and appears to be composed of at least two fully hard linked segments (Figs 2B and 4a). 
The channel crosses the fault through one of the segment boundaries close to the locus of maximum displacement (Fig. 4a). It has a planar geometry with a nearly constant fault plane dip from the seafloor down to the deeper Pliocene strata and the Messinian beneath (Fig. 4c).

A 50-100 m high fault scarp along the central portions of the fault suggests that fault F50 has experienced a higher slip rate than sedimentation rate. Fault scarps generally result from an outpacing of slip rate over sedimentation rate over a prolonged period of time, resulting in an underfilled hangingwall (Back et al., 2006; Cartwright et al., 1998; Castelltort et al., 2004). The onset of synsedimentary fault activity (i.e. as expressed at the seafloor as opposed to the previous blind fault propagation phase) has been interpreted to be reflection P50 as this is where the seismically defined growth package begins (Fig 4b). Using well ties with seismic sections in the adjacent area, P50 is assumed to be Late Pleistocene in age, but it cannot be dated any more precisely. Below P50, reflections in the footwall and hangingwall are parallel, seismic packages exhibit no thickness change across the fault, and the displacement is constant with depth. Above P50, reflections in the hangingwall diverge and seismic packages thicken towards the fault plane, which is characteristic of synkinematic packages associated with normal faults (Thorsen, 1963).

\subsection{The channel system}

The channel is at least $38.5 \mathrm{~km}$ long although it may extend further downslope to the NNW, beyond the extent of the dataset. The degree of sinuosity measured as the alongchannel distance divided by the straight-line distance between the same two points along 
the channel (after Clark et al. (1992)) is 1.23. The channel crosses several normal faults that dip downslope and a few smaller antithetic faults that dip in the opposite direction and thus create small graben features. Fault F50 is crossed at about $10 \mathrm{~km}$ downslope from the apparent head of the channel (Fig. 2).

The width of the channel varies along its length between about $0.3 \mathrm{~km}$ at its narrowest and up to about $2.6 \mathrm{~km}$ at its widest (Fig. 5). Morphology measurements show that there is a systematic variation in channel width, and that width is negatively correlated to the channel thalweg depth, i.e. the channel is generally wider where it is shallower and narrower where it is deeper (Fig. 5). This variation in width and depth is systematic only where the channel is intersected by active faults along its route. The channel is narrow and deep on footwalls and becomes progressively narrower and deeper as it approaches the fault scarp. On crossing the scarp, there are sharp increases in width and sharp decreases in erosion depth on the hangingwall and the channel progressively gets narrower and erodes deeper as it approaches the next fault scarp (Fig. 5b). Where the channel crosses antithetic faults (e.g. f49a, F60) that relationship does not exist, in fact it reverses (Fig. 5b). Another part of the channel where this can be observed is between the two meander turns (M1 and M2) of the down-thrown segment of fault f62 (Figs 2 and 5b). That part of the channel gets deflected by f62 and follows the hangingwall low and as a result its width is constrained and therefore does not reflect the relationship observed on the rest of the channel length.

Prior to the onset of faulting, the area is traversed by several sub-parallel channels as demonstrated on seismic attributes map of a narrow time window from 50 ms above reflection P50 to 50ms below it (Fig. 6). These earlier or precursor channels are barely 
visible on the seismic and are only identified due to their high seismic amplitudes on the RMS amplitude map (Fig. 6). It is common to be able to see small sedimentary features at or just below the level of vertical stratigraphic resolution from such amplitude attribute maps (Rijks and Jauffred, 1991).

An isochron map was constructed from the base of the channel, which is taken to be P50, to the seafloor revealing three areas of thicker sediment accumulations along the length of the channel (Fig. 7). One area is located on the footwall of fault F50 to the east of the channel. The other two are located on the hangingwall of fault F50, on the lee side of meander M2 and immediately upslope of meander M1 (Fig. 7). These sediment accumulations are interpreted as overbank deposits, preferentially depositing where there is accommodation space created by the faults and on the lee side of meanders, where flow stripping occurs due to the centrifugal force (Keevil et al., 2006; Peakall et al., 2000; Piper and Normark, 1983).

The channel is partially infilled with moderate to high amplitude reflections that are likely to be channel margin collapses, particularly on the footwall where the channel margins are steeper due to deep entrenchment, and on the hangingwall sandy gravity flow deposits transported along the channel from an upslope source. This type of infill has been described for buried abandoned channels elsewhere on the Nile Delta (Catterall et al., 2010; Cross et al., 2009). The degree of infill varies down the channel transect: on the footwall it is 'half filled' whereas on the hangingwall it is almost filled to the rim (Fig. 8).

\subsubsection{The slope profiles}


Three slope profiles are used in this study: One is the channel thalweg profile and the other two profiles on either side of the channel (Figs 2 and 7). The two flanking profiles are necessary as controls to conduct the analysis because they represent the seafloor profile in the absence of a channel. Importantly, by comparing them with the thalweg profile, it is possible to identify what effect the channel and the fault have had on the seafloor topography (Fig. 5c).

The three slope profiles are no more than $3 \mathrm{~km}$ apart and are described in detail below.

i) Channel thalweg and upslope profile

The longitudinal depth profile of the channel thalweg consists of alternating concave up and convex segments (Fig. 9). Overall it shows smooth morphology with segments of gentler gradient, $\sim 0.8^{\circ}$, separated by steeper ones of nearly $2.5^{\circ}$, which are coincidental with down-to-basin normal faults (Fig. 9). Upslope of the channel head, the concave parts reflect the presence of two structurally controlled topographic depressions, Depressions I and II, whereas the convex parts of the profile are directly correlated with footwalls, where uplift and back-tilting of fault-bounded blocks has occurred. The two depressions are separated by a footwall crestal region (Fig. 9). The entire Miocene-Pleistocene sequence has been strongly affected by tectonic deformation whereas the infill of the depressions is undeformed (Fig. 9). The base of the channel, that in this location coincides with P50, appears to have truncated reflections of the Miocene-Pleistocene sequence with clear evidence of significant erosion of the footwall of fault F50 on the 
thalweg profile (Fig. 9) which is not observed in the slope profiles on the margins of the channel (Fig. 5c).

By analogy with the fill-and-spill model (Winker, 1996), Depression I is filled to spill whereas Depression II appears only partly filled (dotted line in Fig. 9). Two seismic facies comprise the fill of the depressions; a chaotic assemblage of a moderate to high amplitude reflection facies at the base of the depressions overlain by a seismic facies comprising low to moderate amplitude continuous reflectors which onlap the margins of the depressions (Fig. 9).

ii) Flanking slope profiles

In contrast with the channel thalweg profile, the scarp of fault F50 is clearly visible on these profiles (Fig. 5c) and it is about $150 \mathrm{~m}$ high. The morphology of the profiles is the result of the combined effect of the deformation relating to all these synsedimentary faults. Several fault-controlled knickpoints are visible. The eastern flank seabed profile is smoother than the western flank profile as the fault scarps are either degraded or show smaller offsets. On the hangingwall, the area between the deepest reaching flank slope profile and the channel thalweg represents the degree of slope healing that has been achieved by aggradation in the channel, whereas on the footwall the area between the shallowest flank slope profile and the channel thalweg shows the degree of slope healing that has been achieved by erosion within the channel (Fig. 5c).

\section{Discussion}




\subsection{Relationships between channel morphological evolution and active faulting}

The present-day position of the channel thalweg is the result of aggradation and degradation processes along the channel system (Pirmez et al., 2000) as well as lateral migrations (Labourdette and Bez, 2010). Canyons and channels are commonly deflected by fault escarpments (e.g. Almeria Canyon, SE Spain: Cronin et al. (1995); Israel: Clark and Cartwright (2009); Angola: Anderson et al. (2000). In this study the channel continues on its course across the fault instead of been diverted, deflected, blocked or confined (Clark and Cartwright, 2009).

A RMS amplitude map extracted across an interval 50 ms above and below horizon marker P50 shows the presence of a series of closely spaced channels (Fig. 6). Fault F50 was composed of at least two segments that had not yet hard linked and the channel was utilising a relay ramp between these segments to cross the surface topography related to the fault tips (Fig. 6). Exploitation of relay ramps in this manner is well known from subaerial environments (Commins et al., 2005; Trudgill, 2002). These early channels are not seen on the present-day seafloor so they either avulsed or have converged toward the central channel when the slope was deformed into a convex profile due to fault movements possibly even upon linkage of the F50 segments, in the manner described by (Kneller, 1995). However, there is no direct evidence for either. The channel traverses F50 across the location of maximum displacement which because of the morphology of the linked fault we interpret to be a breached relay ramp (Figs 4a and 6). The fact that the channel continued to flow across the fault post-linkage may be showing that temporarily at least, there were sufficiently vigorous flows down the channel axis, that incision of the channel into the emerging footwall topography could at least get started, and once 
entrenched, it would then be easier for incision to continue even under conditions of lower flow frequency and power. The flank region immediately to the east of the channel is in a state of slope healing as shown by the preferential deposition taking place where there was accommodation space created by hangingwall subsidence. Sediment in this area was supplied by mass transport deposits, normal hemipelagic sedimentation as well as by the channel overspilling preferentially to the right of the flow due to Coriolis (Kolla et al., 2007). As a result the western flank does not appear to be healing to the same degree (Fig. 5c), showing that in this area, the growth of the seafloor depression caused by the fault deformation is faster than the rate of sediment supply that can fill the depression. The only area of relatively increased deposition is near the downslope end of the channel where sediments are accumulating around the outer bend of the channel (Fig. 7), a common feature in meandering channels, due to the action of centrifugal forces (Kolla et al., 2007).

In a sandbox experiment conducted by (Athmer et al., 2010) to examine the impact of submarine relay ramps on turbidity current pathways, most of the sediment tended to pond in the hangingwall depressions. However in the case of F50, it is apparent that the turbidity currents flowing down the channel preferentially incise the footwall, but instead of ponding in the hangingwall continue their downslope course. That may be caused by the presence of more faults that interfere with the equilibrium profile by creating more knickpoints that lead to enhanced erosion (Heiniö and Davies, 2007; Pirmez et al., 2000)In addition, fault linkage across the relay ramp may have resulted in increased erosive ability through footwall uplift leading to increased volume of the flows through erosion thus allowing them to flow further. Hence a positive feedback exists between 
flow power and structurally-controlled seafloor topography where changes in topography generate flow changes.

\subsection{Channel morphology and the significance of the hinge point}

The base of the channel is almost contemporaneous with the onset of synsedimentary fault activity suggesting that erosion within the channel across the backtilted fault blocks commenced synchronously with fault displacement as indicated by the truncated reflections in figure 9. When compared with the profiles on the flanks of the channel it is evident that the thalweg profile responded immediately to all the separate coupled uplift-subsidence displacements of the slope as the channel crosses several faults, in most cases perpendicularly. This is a fundamental conclusion: the balance of erosional power in the channel resulting from some unspecified frequency of flows was sufficient to keep pace with the uplift and back-rotation of the slope profile in the footwall. It seems likely therefore, that incision began at the point demarcating the boundary between areas subject to footwall uplift from those that were too far from the fault to experience any such uplift. In this study this position is referred to as the hinge point (Fig. 9). Landward of each hinge point, the fault block topography is that of the hangingwall where accommodation space is created and sediment can accumulate. The channel there is wider and shallower. Basinward of this point the fault block has the topographic expression of an active footwall to the next fault located downslope where gravity flows encounter the negative gradient of the uplifted segment and therefore erode in order to maintain the gradient. As a result the channel becomes deeper and narrower (Fig. 5b). Maximum incision takes place at the crossing of a fault escarpment, which is where 
maximum displacement on the fault and the maximum locus of footwall uplift are located (Fig. 5b). Likewise maximum width is observed immediately after crossing the fault on the hangingwall (Fig. 5). It is likely that the alternations actually take place at the hinge point (Fig. 9). The hinge point thus relates with gradient changes on the slope profile. Changes in channel morphological parameters in response to gradient changes are not uncommon and have been described elsewhere (e.g. Lower Congo Basin (Ferry et al., 2005)and the Amazon (Pirmez and Flood, 1995).

\subsection{Slope healing processes upslope of channel}

Depressions I and II were both located upslope of the start of the channel, on the hangingwalls of two faults; Depression I by several minor faults (Fig. 9) and Depression II by F40 (Fig. 9). These structural depressions have asymmetric morphologies reflecting their genetic link to normal faults on their upslope margin. According to the fill-and-spill model of Beaubouef and Friedman (2000), onset of basin infilling begins first in the basin closest to the shelf, Depression I in this case, and progresses seaward as this basin is filled to a spill point. The accommodation space in Depression I is filled to grade (Fig. 9), i.e. filled to the local position of the equilibrium profile (Kneller, 2003) which tends to occur where depositional rates exceed rates of formation of the accommodation space (Prather et al., 1998). The acoustic character of the infill suggests it consists of mass transport deposits (MTD) and hemipelagites (Fig. 9). The filling sequence of Depression II is truncated by the erosional surface that marks the base of the channel (Fig. 9). This suggests that Depression II was either filled-to-spill or near to the spill phase when displacement on F50 created a hinge point where incision started coincident with the 
head of the channel. The hinge point at that stage became the new spill point for the basin. The erosion of its infill sequence then would have contributed to locally feeding the channel.

The infill history of the slope in this area, and specifically in the fault-controlled depressions started with a mass transport basal deposit as indicated by the acoustically chaotic seismic sequence (MTD in Fig. 9). It is possible that slope collapses occurred further upslope, due to local slope oversteepening along fault escarpments, and these upslope failures might then have generated through flow transformation the gravity flows that incise this channel. Currently, there is no evidence of slope instability on the presentday seafloor within the available dataset but (Loncke et al., 2009) have documented the area upslope of the channel as slumped seafloor (their figure 7, p. 640).

\subsection{Slope model and significance for hydrocarbon reservoirs}

A simplified concept of the evolution of the slope in the studied area, without taking into consideration the effect of the other faults present, is presented in Figure 10. Before the segments of fault F50 linked to form one fault, small channels were traversing the slope, across the F50 segments and through the relay ramp, being fed by slope failures from upslope (time T0). Upon fault linkage slope topography would have become such that the channels crossing the fault segments either avulsed and backfilled or coalesced towards the central channel that was originally flowing through the relay ramp. A knickpoint and a hinge point formed on the thalweg profile of that channel (T1) causing sediment flows on the footwall to decelerate and partially deposit. Incision, thus, begun on the footwall. On the hangingwall the channel widened due to the gradient change but because of the 
formation of the fault scarp and the knickpoint flows would accelerate and hydraulic jumps would most likely be generated. As a result incision and deposition would be taking place at that time and possibly build up of small levees. With more uplift on the footwall any tributaries would also avulse and extensive erosion caused deep entrenchment of the channel on the footwall while gradual deposition on the hangingwall led to infill and loss of the levees (T2). This is the present day situation and what can be observed on the seafloor and the thalweg slope profile. The slope profile will eventually reach a temporary equilibrium and get draped and any flows that might move across this area will bypass, until fault F50 or any of the other faults gets reactivated in which case another cycle of erosion and deposition will begin in order to bring the slope profile back to equilibrium.

In terms of hydrocarbon reservoir quality the footwall originally was dominated by channelized, low net-to-gross (n:g) and low permeability reservoirs within stratigraphic traps which after fault linkage would transition to still channelized but larger reservoirs with higher n:g but internal flow barriers would be introduced. With increasing entrenchment the n:g would likely decrease as most of the sand gets carried downslope. On the hangingwall originally thin sheet sandstones in stratigraphic traps with potentially good connectivity would be expected. With fault linkage and dominant deposition a high n:g reservoir is expected to have formed possibly containing flow barriers due to the formation of muddy levees. The subsequent infill of the channel possibly resulted in a high n:g reservoir with good connectivity and a potentially competent seal to mud deposition and hemipelagic draping. However, the real picture is not as simple. For this model all the other faults were ignored (dashed lines in T1-T2) but in terms of reservoir 
quality they will have a significant impact in forming structural traps (Prather, 2003), compartmentalising the sands and play an unknown role in connectivity depending on what layers they bring to contact (Moller et al., 2004) as well as in seal effectiveness (Cartwright et al., 2007).

\subsection{Implications for the equilibrium profile concept}

This study has shown that where changes in slope topography due to structural deformation are smaller than the cumulative erosional power of a succession of flows in a given time interval, the channel will seek to establish the equilibrium profile through erosion and aggradation. Local factors such as the timing interplay in breaching of relay ramps, and the coalescing of precursor channels played a significant part in preconditioning the structurally controlled topography such that the initial incisional response of the main channel was effective in countering the footwall uplift.

Furthermore, even in an area of the slope where sediment flows were probably infrequent it is rather the rate of tectonic movement that dictates how the channel behaves and it is the interplay of the faults that controls the shape of the slope profiles. Footwalls tend to create concave profiles with erosion beginning at the hinge point.

From this study it can be inferred then that a slope in equilibrium is energy-efficient for the flow with no kinetic barriers allowing it to follow a direct pathway downslope under the force of gravity. In the end the channel and the gravity flows within it will follow the route of least resistance, which will be the most energy efficient. In the case of higher tectonic rates perhaps it is more energy efficient to flow around the structure rather than erode through it. In the end perhaps this is what the equilibrium profile is, the way 
for a fluid flow to get from source to base level in the most direct way by conserving as much energy as possible. Although we have not quantified how much energy can be conserved this way, it would be interesting in future research in this topic to see models that demonstrate it.

\section{Conclusions}

1. When the rate of fault displacement is relatively slow the combination of channel erosion and aggradation results in a smooth profile approaching equilibrium.

2. The equilibrium profile can be reached even when sediment supply is infrequent as tectonic movement dictates how the channel will behave.

3. Footwalls create concave slope profiles and erosion starts at the hinge point.

4. Local factors such as breaching of relay ramps and the coalescing of precursor channels played a significant part in preconditioning the structurally controlled topography.

5. The best reservoirs in terms of n:g and connectivity form on the hanging wall. However the quality of the reservoirs and effectiveness of the seal may be significantly impaired by the presence of more faults.

6. Turbidite channels will only conform to the concept of equilibrium and submarine base level if this is the most energy efficient route, i.e. when flows bypass the slope without eroding or depositing and move directly to base level.

\section{Acknowledgements}


We wish to thank BP for making the dataset available to the 3DLab and to the CAPROCKS consortium and for permitting the release of this paper. A. Georgiopoulou would like to also acknowledge funding from the CAPROCKS consortium as well as a Griffith Geoscience Research Award of the Department of Communications, Energy and Natural Resources (under the National Geoscience Programme 2007-2013, Ireland). Conversations with colleagues both in the 3DLab and at UCD, and in particular with Drs Ian Clark, Peter Haughton and Conrad Childs, greatly contributed in the formulation of ideas expressed in this work. Comments by three anonymous reviewers and the editor, Dr Ian Kane, improved the quality of the paper and are much appreciated.

\section{References}

Aal, A.A., El Barkooky, A., Gerrits, M., Meyer, H., Schwander, M., Zaki, H., 2000. Tectonic evolution of the Eastern Mediterranean Basin and its significance for hydrocarbon prospectivity in the ultradeepwater of the Nile Delta. The Leading Edge, 19, 1086-1102.

Anderson, J.E., Cartwright, J., Drysdall, S.J., Vivian, N., 2000. Controls on turbidite sand deposition during gravity-driven extension of a passive margin: examples from Miocene sediments in Block 4, Angola. Marine and Petroleum Geology, 17, 1165-1203.

Arzola, R.G., Wynn, R.B., Lastras, G., Masson, D.G., Weaver, P.P.E., 2008. Sedimentary features and processes in the Nazare and Setubal submarine canyons, west Iberian margin. Marine Geology, 250, 64-88.

Athmer, W., Groenenberg, R.M., Luthi, S.M., Donselaar, M.E., Sokoutis, D., Willingshofer, E., 2010. Relay ramps as pathways for turbidity currents: a study combining analogue sandbox experiments and numerical flow simulations.

Sedimentology, 57, 806-823.

Back, S., Höcker, C., Brundiers, M.B., Kukla, P.A., 2006. Three-dimensional-seismic coherency signature of Niger Delta growth faults: integrating sedimentology and tectonics. Basin Research, 18, 323-337.

Barnett, J.A.M., Mortimer, J., Rippon, J.H., Walsh, J.J., Watterson, J., 1987.

DIisplacement geometry in the volume containing a single normal fault. AAPG Bulletin, 71, 925-937.

Baudon, C., Cartwright, J.A., 2008. 3D seismic characterisation of an array of blind normal faults in the Levant Basin, Eastern Mediterranean. Journal of Structural Geology, 30, 746-760. 
Beaubouef, R.T., Friedman, S.J., 2000. High-resolution seismic/sequence stratigraphic framework for the evolution of Pleistocene intra slope basins, Western Gulf of Mexico: depositional models and reservoir analogs, in: Weimer, P., Slatt, R.M., Coleman, J., Rosen, N.C., Nelson, H., Bouma, A.H., Styzen, M.J., Lawrence, D.T. (Eds.), Deep-Water Reservoirs of the World: Gulf Coast Society of the Society of Economic Paleontologists and Mineralogists Foundation, 20th Annual Research Conference, pp. 40-60.

Bellaiche, G., Loncke, L., Gaullier, V., Mascle, J., Courp, T., Moreau, A., Radan, S., Sardou, O., 2001. The Nile Cone and its channel system: new results after the Fanil cruise. Comptes Rendus De L Academie Des Sciences Serie Ii Fascicule a-Sciences De La Terre Et Des Planetes, 333, 399-404.

Bellaiche, G., Zitter, T., Droz, L., Gaullier, V., Mart, Y., Mascle, J., 1999. The Nile Cone: main results of the Prismed II cruise of the R. V. L'Atalante. Comptes Rendus De L Academie Des Sciences Serie Ii Fascicule a-Sciences De La Terre Et Des Planetes, 329, 727-733.

Carter, R.M., 1988. The nature and evolution of deep-sea channel systems. Basin Research, 1, 41-54.

Cartwright, J., Bouroullec, R., James, D., Johnson, H., 1998. Polycyclic motion history of some Gulf Coast growth faults from high-resolution displacement analysis. Geology, 26, 819-822.

Cartwright, J., Huuse, M., Aplin, A., 2007. Seal bypass systems. AAPG Bulletin, 91, 1141-1166.

Cartwright, J.A., Trudgill, B.D., Mansfield, C.S., 1995. Fault growth by segment linkage - An explanation for scatter in maximum displacement and trace length data from the canyonland grabens of SE Utah. Journal of Structural Geology, 17, 1319-1326. Castelltort, S., Pochat, S., Van Den Driessche, J., 2004. Using T-Z plots as a graphical method to infer lithological variations from growth strata. Journal of Structural Geology, 26, 1425-1432.

Catterall, V., Redfern, J., Gawthorpe, R., Hansen, D., Thomas, M., 2010. Architectural Style and Quantification of a Submarine Channel-Levee System Located in a Structurally Complex Area: Offshore Nile Delta. Journal of Sedimentary Research, 80, 991-1017. Catuneanu, O., 2002. Sequence stratigraphy of clastic systems: concepts, merits, and pitfalls. Journal of African Earth Sciences, 35, 1-43.

Clark, I.R., Cartwright, J.A., 2009. Interactions between submarine channel systems and deformation in deepwater fold belts: Examples from the Levant Basin, Eastern Mediterranean sea. Marine and Petroleum Geology, 26, 1465-1482.

Clark, J.D., Kenyon, N.H., Pickering, K.T., 1992. Quantitative-analysis of the geometry of submarine channels - Implications for the classification of submarine fans. Geology, 20, 633-636.

Commins, D., Gupta, S., Cartwright, J., 2005. Deformed streams reveal growth and linkage of a normal fault array in the Canyonlands graben, Utah. Geology, 33, 645-648. Cronin, B.T., Akhmetzhanov, A.M., Mazzini, A., Akhmanov, G., Ivanov, M., Kenyon, N.H., Scientists, T.T.R.S., 2005. Morphology, evolution and fill: Implications for sand and mud distribution in filling deep-water canyons and slope channel complexes.

Sedimentary Geology, 179, 71-97.

Cronin, B.T., Kenyon, N.H., Woodside, J.M., Ivanov, M., den Bezemer, T., Millington, J., Van Der Wal, A., Limonov, A., 1995. Views of the Andarax submarine canyon: a 
meandering system on an active tectonic margin., in: Pickering, K.T., Hiscott, N., Smith, R., Kenyon, N.H. (Eds.), Atlas of Deep Water Environments Architectural Style in Turbidite Systems. Chapman and Hall, London, pp. 84-88.

Cross, N.E., Cunningham, A., Cook, R.J., Taha, A., Esmaie, E., El Swidan, N., 2009. Three-dimensional seismic geomorphology of a deep-water slope-channel system: The Sequoia field, offshore west Nile Delta, Egypt. AAPG Bulletin, 93, 1063-1086.

Dietz, R.S., 1963. Wave-Base, Marine Profile of Equilibrium, and Wave-Built Terraces: A Critical Appraisal. Geological Society of America Bulletin, 74, 971-990.

Ducassou, E., Migeon, S., Mulder, T., Murat, A., Capotondi, L., Bernasconi, S.M., Mascle, J., 2009. Evolution of the Nile deep-sea turbidite system during the Late Quaternary: influence of climate change on fan sedimentation. Sedimentology, 56, 20612090.

Ferry, J.-N., Mulder, T., Parize, O., Raillard, S., 2005. Concept of equilibrium profile in deep-water turbidite systems: effects of local physiographic changes on the nature of sedimentary process and teh geometries of deposits, in: Hodgson, D.M., Flint, S.S. (Eds.), Submarine slope systems: processes and products. Geological Society of London, Special Publication London, pp. 181-193.

Gardner, T.W., 1983. Experimental study of knickpoint and longitudinal profile evolution in cohesive, homogeneous material. Geological Society of America Bulletin, 94, 664-672. Garziglia, S., Migeon, S., Ducassou, E., Loncke, L., Mascle, J., 2008. Mass-transport deposits on the Rosetta province (NW Nile deep-sea turbidite system, Egyptian margin): Characteristics, distribution, and potential causal processes. Marine Geology, 250, 180198.

Gerber, T.P., Amblas, D., Wolinsky, M.A., Pratson, L.F., Canals, M., 2009. A model for the long-profile shape of submarine canyons. J. Geophys. Res., 114, F03002.

Heiniö, P., Davies, R.J., 2007. Knickpoint migration in submarine channels in response to fold growth, western Niger Delta. Marine and Petroleum Geology, 24, 434-449.

Howard, A.D., Dietrich, W.E., Seidl, M.A., 1994. Modeling fluvial erosion on regional to continental scales Journal of Geophysical Research-Solid Earth, 99, 13971-13986.

Keevil, G.M., Peakall, J., Best, J.L., Amos, K.J., 2006. Flow structure in sinuous submarine channels: Velocity and turbulence structure of an experimental submarine channel. Marine Geology, 229, 241-257.

Kneller, B., 1995. Beyond the turbidite paradigm: physical models for deposition of turbidites and their implications for reservoir prediction., in: Hartley, A.J., and D.J. Prosser (Ed.), Characterization of deep marine clastic systems. Geological Society Special Publication, pp. 31-49.

Kneller, B., 2003. The influence of flow parameters on turbidite slope channel architecture. Marine and Petroleum Geology, 20, 901-910.

Kolla, V., Posamentier, H.W., Wood, L.J., 2007. Deep-water and fluvial sinuous channels - Characteristics, similarities and dissimilarities, and modes of formation. Marine and Petroleum Geology, 24, 388-405.

Kreemer, C., Chamot-Rooke, N., 2004. Contemporary kinematics of the southern Aegean and the Mediterranean Ridge. Geophysical Journal International, 157, 1377-1392. Labourdette, R., Bez, M., 2010. Element migration in turbidite systems: Random or systematic depositional processes? AAPG Bulletin, 94, 345-368. 
Lastras, G., Arzola, R.G., Masson, D.G., Wynn, R.B., Huvenne, V.A.I., Huhnerbach, V., Canals, M., 2009. Geomorphology and sedimentary features in the Central Portuguese submarine canyons, Western Iberian margin. Geomorphology, 103, 310-329.

Le Pichon, X., Chamotrooke, N., Lallemant, S., Noomen, R., Veis, G., 1995. Geodetic Determination of the Kinematics of Central Greece with Respect to Europe - Implications for Eastern Mediterranean Tectonics. Journal of Geophysical Research-Solid Earth, 100, $12675-12690$.

Loncke, L., Gaullier, V., Bellaiche, G., Mascle, J., 2002. Recent depositional patterns of the Nile deep-sea fan from echo-character mapping. AAPG Bulletin, 86, 1165-1186.

Loncke, L., Gaullier, V., Droz, L., Ducassou, E., Migeon, S., Mascle, J., 2009. Multiscale slope instabilities along the Nile deep-sea fan, Egyptian margin: A general overview. Marine and Petroleum Geology, 26, 633-646.

Loncke, L., Gaullier, V., Mascle, J., Vendeville, B., Camera, L., 2006. The Nile deep-sea fan: An example of interacting sedimentation, salt tectonics, and inherited subsalt paleotopographic features. Marine and Petroleum Geology, 23, 297-315.

Loncke, L., Mascle, J., 2004. Mud volcanoes, gas chimneys, pockmarks and mounds in the Nile deep-sea fan (Eastern Mediterranean): geophysical evidences. Marine and Petroleum Geology, 21, 669-689.

Mascle, J., Benkhelil, J., Bellaiche, G., Zitter, T., Woodside, J., Loncke, L., 2000. Marine geologic evidence for a Levantine-Sinai plate, a new piece of the Mediterranean puzzle. Geology, 28, 779-782.

Mascle, J., Sardou, O., Loncke, L., Migeon, S., Camera, L., Gaullier, V., 2006. Morphostructure of the Egyptian continental margin: Insights from swath bathymetry surveys. Marine Geophysical Researches, 27, 49-59.

Mascle, J., Zitter, T., Bellaiche, G., Droz, L., Gaullier, V., Loncke, L., 2001. The Nile deep sea fan: preliminary results from a swath bathymetry survey. Marine and Petroleum Geology, 18, 471-477.

Mayall, M., Lonergan, L., Bowman, A., James, S., Mills, K., Primmer, T., Pope, D., Rogers, L., Skeene, R., 2010. The response of turbidite slope channels to growth-induced seabed topography. AAPG Bulletin, 94, 1011-1030.

McClusky, S., Balassanian, S., Barka, A., Demir, C., Ergintav, S., Georgiev, I., Gurkan, O., Hamburger, M., Hurst, K., Kahle, H., Kastens, K., Kekelidze, G., King, R., Kotzev, V., Lenk, O., Mahmoud, S., Mishin, A., Nadariya, M., Ouzounis, A., Paradissis, D., Peter, Y., Prilepin, M., Reilinger, R., Sanli, I., Seeger, H., Tealeb, A., Toksoz, M.N., Veis, G., 2000. Global Positioning System constraints on plate kinematics and dynamics in the eastern Mediterranean and Caucasus. Journal of Geophysical Research-Solid Earth, 105, 5695-5719.

Moller, N.K., Gjelberg, J.G., Martinsen, O., Charnock, M.A., Faerseth, R.B., Sperrevik, S., Cartwright, J.A., 2004. A geological model for the Ormen Lange hydrocarbon reservoir. Norwegian Journal of Geology, 84, 169-190.

Mulder, T., Syvitski, J.P.M., Migeon, S., Faugères, J.-C., Savoye, B., 2003. Marine hyperpycnal flows: initiation, behavior and related deposits. A review. Marine and Petroleum Geology, 20, 861-882.

Peakall, J., McCaffrey, B., Kneller, B., 2000. A process model for the evolution, morphology, and architecture of sinuous submarine channels. Journal of Sedimentary Research, 70, 434-448. 
Piper, D.J.W., Normark, W.R., 1983. Turbidite depositional patterns and flow characteristics, Navy Submarine Fan, California Borderland. Blackwell Publishing Ltd, pp. 681-694.

Pirmez, C., Beaubouef, R.T., Friedman, G.M., Mohrig, D.C., 2000. Equilibrium profile and baselevel in submarine channels: Examples from Late Pleistocene systems and implications for the architecture of deepwater reservoirs, in: Weimer, P., Slatt, R.M., Coleman, J.M., Rosen, N.C., Nelson, H., Bouma, A.H., Stytzen, M.J., Lawrence, D.T. (Eds.), Deep-water reservoirs of the world. Gulf Coast Section SEPM, Houston, Texas, pp. 782-805.

Pirmez, C., Flood, R.D., 1995. Morphology and structure of Amazon Channel. Ocean Drilling Program, College Station, TX, ETATS-UNIS.

Prather, B.E., 2003. Controls on reservoir distribution, architecture and stratigraphic trapping in slope settings. Marine and Petroleum Geology, 20, 529-545.

Prather, B.E., Booth, J.R., Steffens, G.S., Craig, P.A., 1998. Classification, lithologic calibration, and stratigraphic succession of seismic facies of intraslope basins, deep-water Gulf of Mexico. AAPG Bulletin, 82, 701-728.

Rijks, E.J.H., Jauffred, J.C.E.M., 1991. Attribute extraction: An important application in any detailed 3D interpretation study. The Leading Edge, 10, 11-19.

Ross, D., Uchupi, E., 1977. Structure and sedimentary history of Southeastern Mediterranean Sea-Nile Cone area. American Association of Petroleum Geologists Bulletin, 61, 872-902.

Thorsen, C.E., 1963. Age of growth faulting in the southeast Louisiana. Transactions of the Gulf Coast Association of Geological Sciences, 13, 103-110.

Trudgill, B.D., 2002. Structural Controls on Drainage Development in the Canyonlands Grabens of Southeast Utah. AAPG Bulletin, 86, 1095-1112.

Walsh, J.J., Watterson, J., 1987. Distributions of cumulative displacement and seismic slip on a single normal fault surface. Journal of Structural Geology, 9, 1039-1046. Westaway, R., 1994. Present-Day Kinematics of the Middle-East and Eastern Mediterranean. Journal of Geophysical Research-Solid Earth, 99, 12071-12090. Winker, C.D., 1996. High-resolution seismic stratigraphy of a late Pleistocene submarine fan ponded by salt-withdrawal mini-basins on the Gulf of Mexico continental slope, 28th Annual Offshore Technology Conference, pp. 619-628.

\section{Figures}

Fig.1 Schematic illustration of subaerial and submarine equilibrium profiles in relation to slope profile and anticipated erosional and depositional processes (modified from Catuneanu (2002), Dietz (1963) and Kneller (2003)). 
Fig. 2 A) Grey shaded bathymetry of the Nile Deep Sea Fan and Egyptian continental platform (modified from Mascle et al. (2006) with inset map of the Eastern Mediterranean. B) Dip attribute map of the seabed over the 3D survey area with inset map showing a more extensive part of the study area (C). Faults whose traces are not very clear have been drawn in with red.

Fig. 3 Block diagram of channel morphometric parameters that were used to characterise the channel in this study.

Fig. 4 (a) Throw profiles along four horizons intersected by the fault F50 measured along the fault trace on lines crossing points (red circles) on (b) and (c) seismic line showing the horizons. The location of the channel crossing the fault as well as the two linking fault segments are also indicated. Accuracy of throw values is approximately $5 \mathrm{~ms}$ (TWT). For location see Fig. 2.

Fig. 5 (a) Channel thalweg profile aligned with (b) corresponding graphs of depth of channel thalweg and channel width measured along its length. The arrows in b indicate the positions of the faults marked on the profile (aligned). Note that maximum incision is observed on the footwalls just behind the fault scarps and maximum width is observed on the hangingwalls. This negative relationship alternates downslope as the channel crosses several faults. However there is an inverse relationship on the hangingwall of fault f62, between meanders M1 and M2 (for location see fig. 2B), which actually deflects the 
channel. (c) Channel thalweg profile together with flank profiles showing by comparison where the channel has eroded and where it has deposited. In red a theoretical equilibrium profile shows that the channel is out-of-equilibrium as the profile is not perfectly smooth (knickpoints marked with kp) but in places it is approaching equilibrium.

Fig. 6 (a) RMS amplitude map over a time window $50 \mathrm{~ms}$ above to $50 \mathrm{~ms}$ below the Horizon P50 and (b) associated interpretation. This map shows at least five channels on the slope, and one (strong black line) utilising the relay ramp between the two fault segments that later formed fault F50. Seismic section (c) shows the position of these streams marked with arrows. The green solid line shows reflection P50. The yellow dashed line separates packages of different acoustic character; strong parallel reflector above, compared to low-moderate amplitude reflectors punctuated by some stronger ones below.

Fig. 7 Isochron map of the interval calculated between the seafloor and P50 overlain on the seabed dip map of the survey area. Contour interval is $50 \mathrm{~ms}$ TWT. The isochron map shows sediment thickness increases on the right side of the channel on the footwall and on the lee sides of two meanders marked M1 and M2. Also evident is Depression II. The dashed lines show the location of the slope profiles used in figures 5c and 9.

Fig. 8 Seismic sections across the channel on the footwall (a-c) and the hangingwall (d-f) showing the degree of infill (marked with blue shading). The channel is significantly 
more infilled on the hangingwall. Faults are shown in red. Seafloor, Reference marker and P50 of figure 4 are also indicated. For locations see Fig. 2.

Fig. 9 Seismic longitudinal slope profile of the channel thalweg and upslope extension to include Depressions I and II with corresponding interpretation. P50 is indicated with a thick black line and the erosional base of the channel (the base of channel infill) with thick dashed line. The hatched area indicates the block of slope that is missing and has been eroded because of uplift and back-tilt on fault F50. The thin dashed line over Depression II shows the part of the slope that still needs to be infilled for the basin to be filled-to-spill. Knickpoints pointed out by arrows suggest the profile is not yet in equilibrium.The locations of cross-sections 8a-f are also indicated. Data below the Top Messinian are clipped by the Operator. For location see Fig. 2.

Fig. 10 (A) Simplified conceptual model showing the response of the channel thalweg profile to linkage of the two segments that form fault F50. Not to scale. At time T1 when fault F50 offsets the channel thalweg from equilibrium a hinge point and a knickpoint are formed. Flows decelerate and partially deposit at the hinge point but the knickpoint causes flow acceleration and erosion on the footwall and deposition on the hangingwall (T2). The channel thalweg will eventually acquire the equilibrium profile and get draped. (B) At time $\mathrm{T} 0$ the slope is traversed by several small channels, one of them utilises the relay ramp between to fault segments. The channels on the footwall avulse or coalesce toward the central channel which incises the fault scarp (T0-T1). (B) 3D cartoons illustrating key stages of the slope response to fault F50 hard linkage and hydrocarbon 
reservoir potential and likely internal characteristics. Times T0, T0-T1 and T1-T2

correspond to T0-T2 in (A). This shows that the potentially good reservoirs would only be found on the hangingwall; thin sheet sand reservoirs when small channels traversed the slope to more channelized sands and potentially small levees to fully channelized after fault segment hard linkage (See text for more detail). 
head of subaerial equilibrium profile

\section{SUBAERIAL}

MARINE erosion

$\because::::$ deposition

- slope profile equilibrium profile fluvial erosion

wave scrouring

canyon incision subaerial $=$ sea level

processes base level
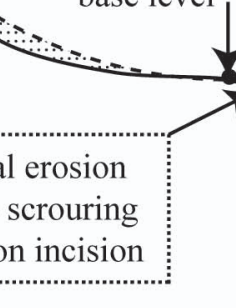

\section{- head of submarine} equilibrium profile

submarine

channel processes
D

marine

base level 

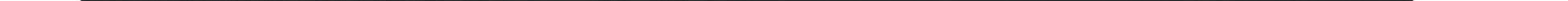


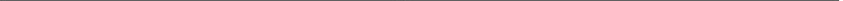


(a)
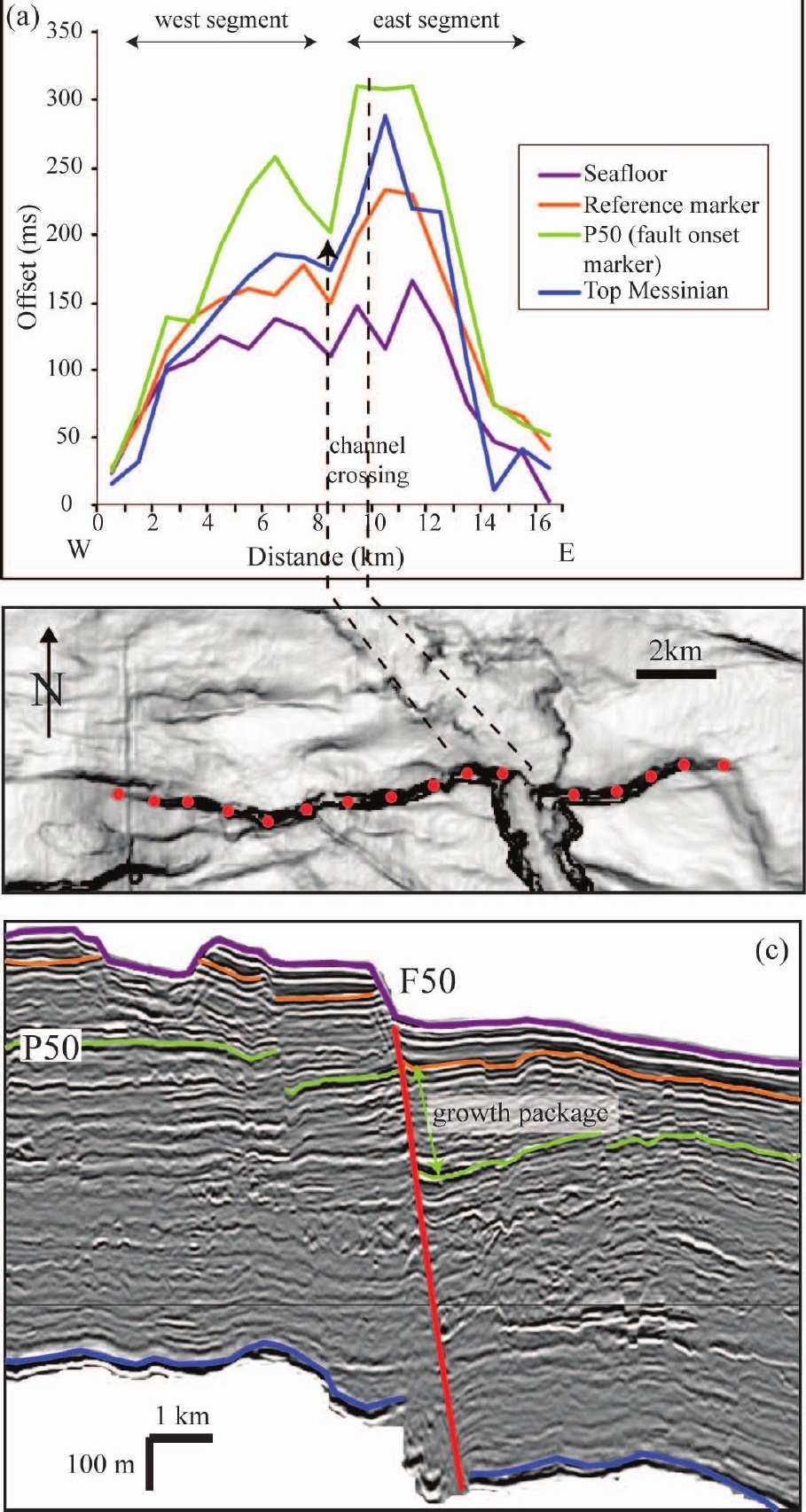
(a)

distance $(\mathrm{km})$
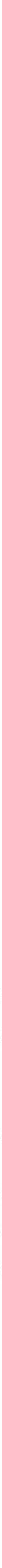

(c)

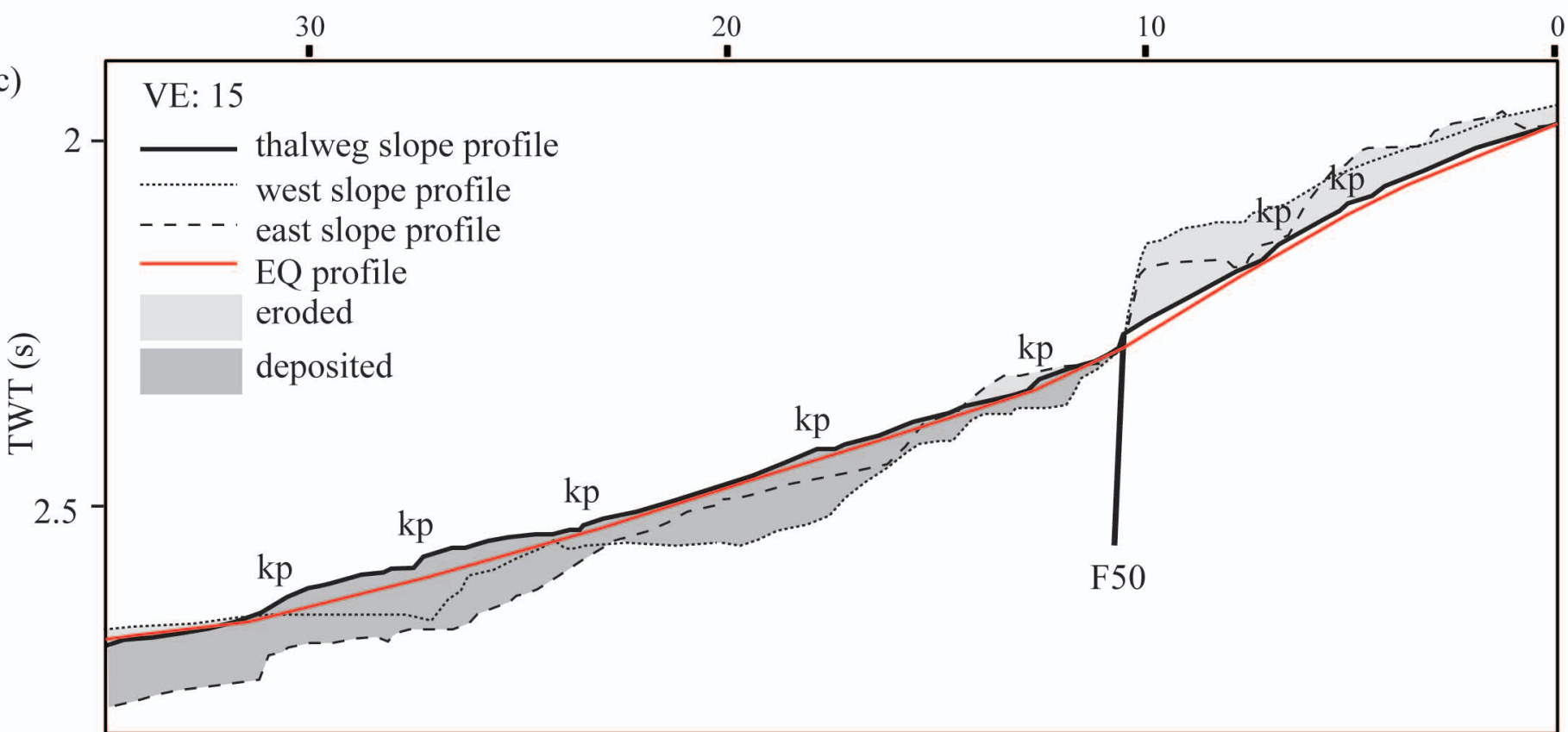


$29^{\circ} \mathrm{OO} 0^{\prime} \mathrm{E} \quad 29^{\circ} \mathrm{O4^{ \prime } \mathrm { E }} \quad 29^{\circ} \mathrm{O8^{ \prime } \mathrm { E }} \quad 29^{\circ} 12^{\prime} \mathrm{E} \quad 29^{\circ} 16^{\prime} \mathrm{E}$

$31^{\circ} 48^{\prime} \mathrm{N}$
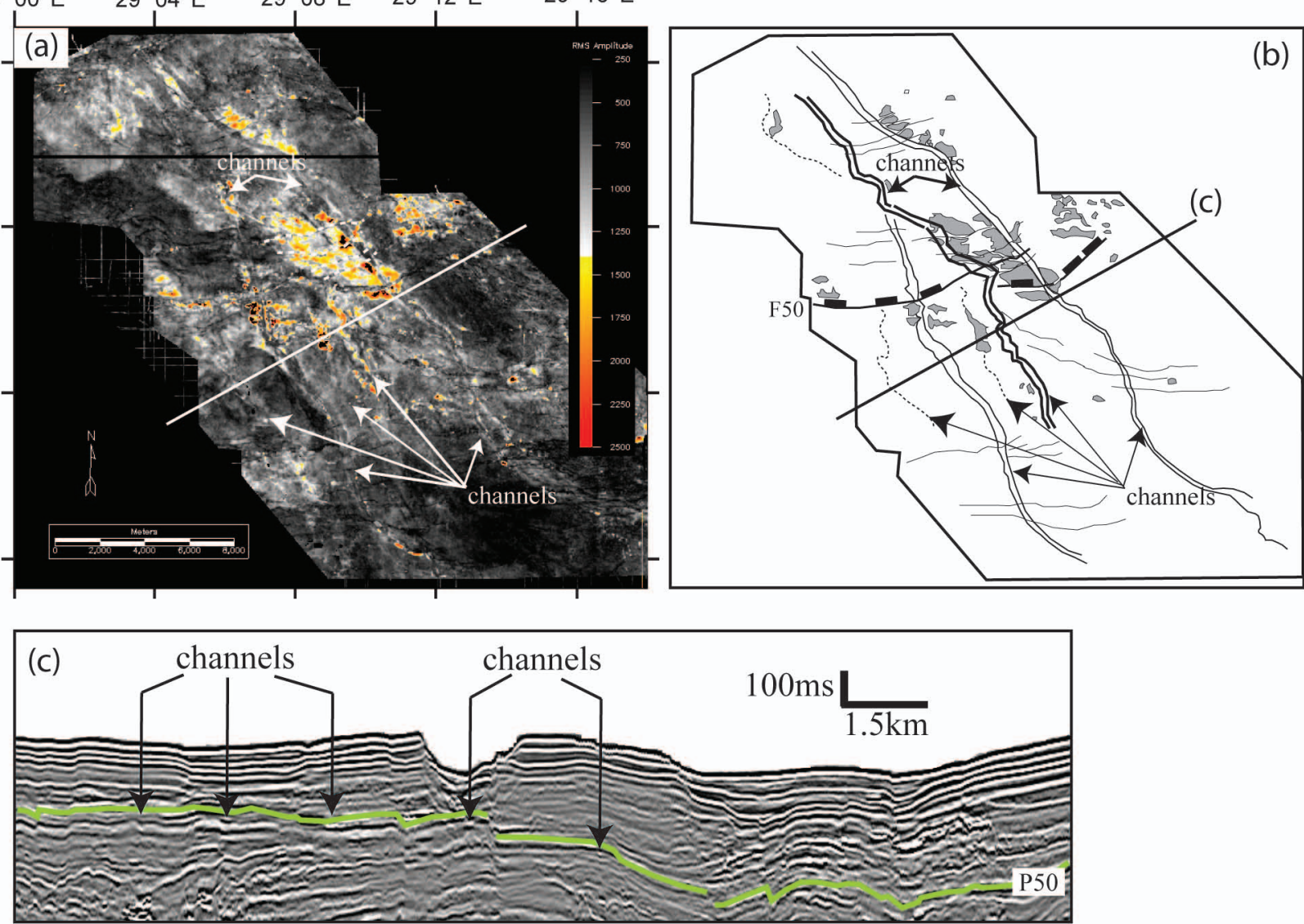


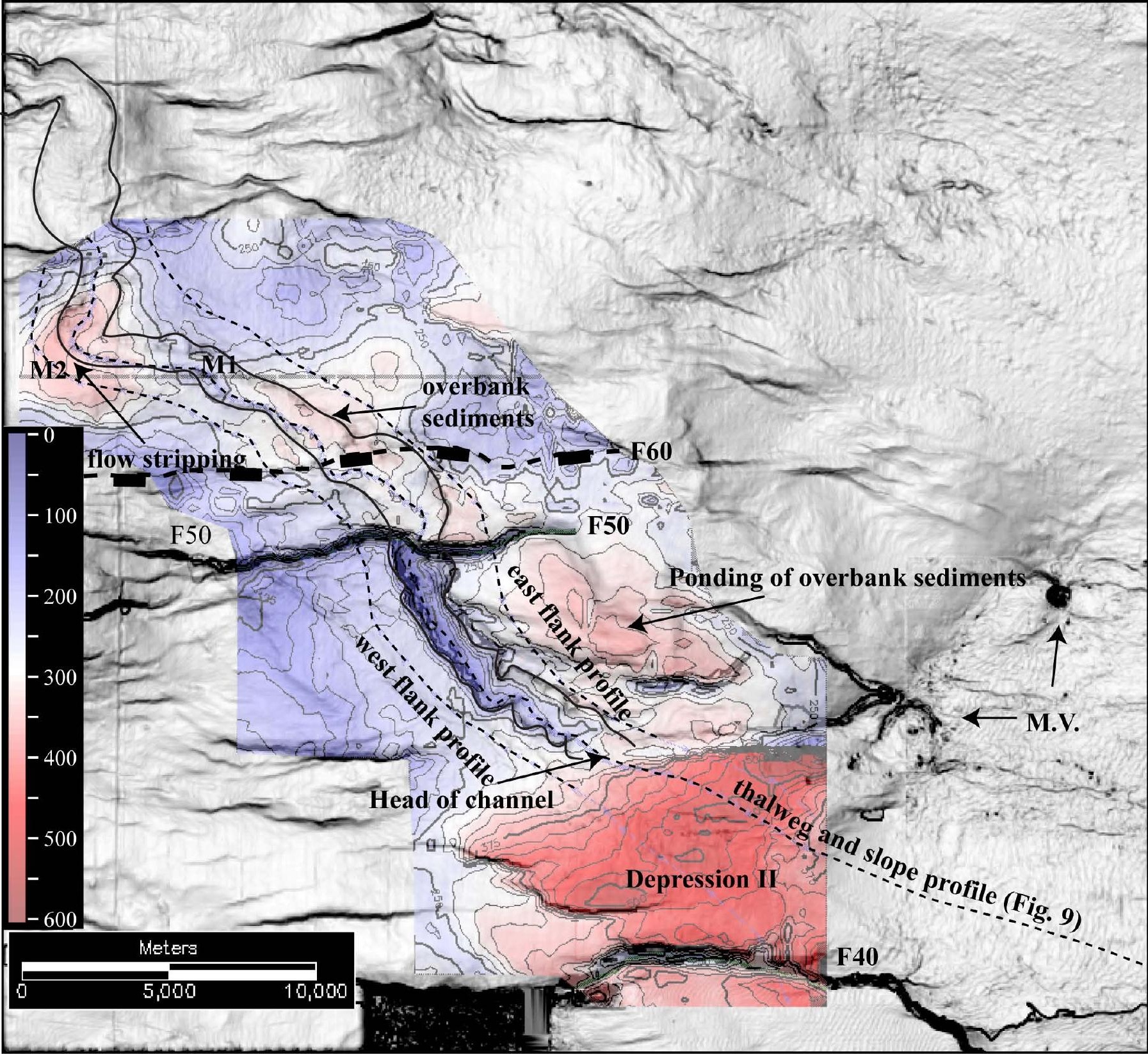



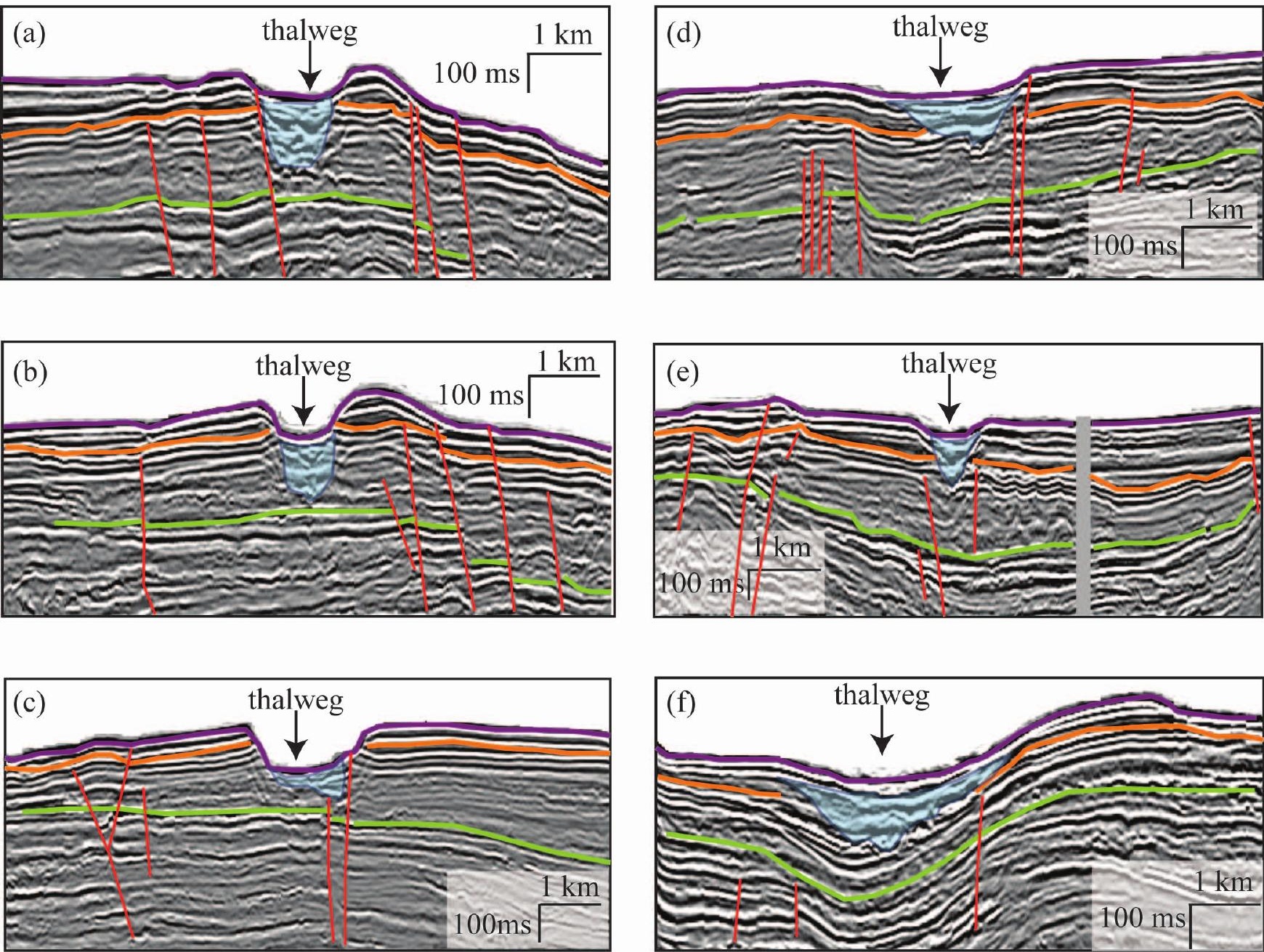

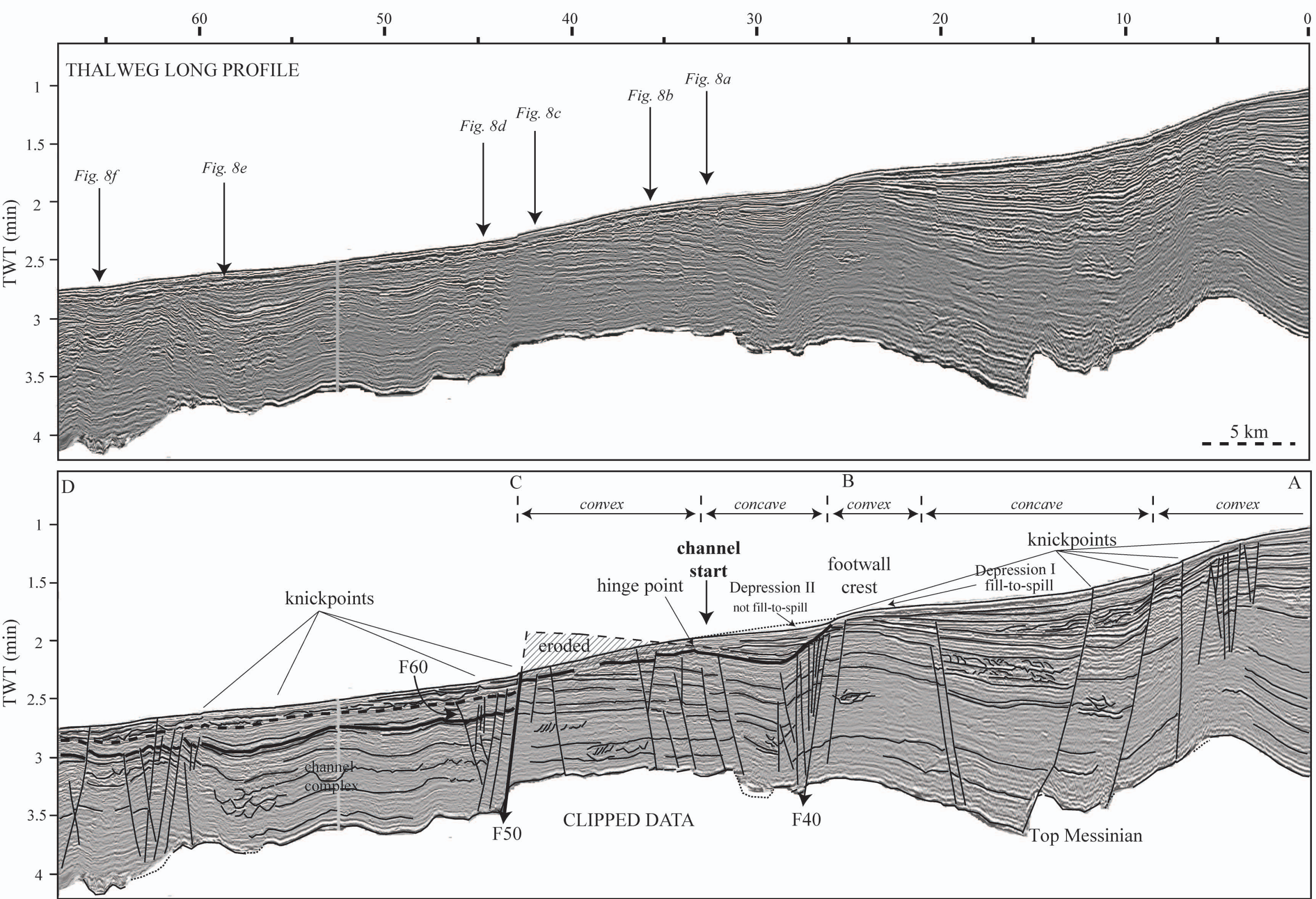
